\title{
9
}

\section{Ideology and professionalism: the resurgence of the Vietnamese bar}

\author{
Nguyen Hung Quang and Kerstin Steiner
}

The legal profession is crucial to a democratic society and is one of speciality. The legal profession is, primarily, necessary to ensure the constitutional rights of the citizen, the right to be protected, and the right to defense counsel where rights and interests are violated.

Nguyen Dinh Loc (2001)

Minister of Justice

In the cause of building a socialist state based on rule of law, the Communist Party of Vietnam and the Government of Vietnam have issued a number of resolutions, directives and legal normative documents to improve the state apparatus and laws (Hoang The Lien 2002). In early 2001, as part of the legal reform process, the Politburo of the Party Central Committee issued a resolution on future reforms to the judicial branch, ${ }^{1}$ laying the foundation for legal reform in Vietnam and resulting in a number of legal normative documents being passed. These documents regulated judicial activities and generally supported the aim of building a law-based socialist state in Vietnam.

This chapter seeks to analyse how individual lawyers and their organisations can be strengthened and consolidated as part of Vietnam's legal reform. In order to address this issue, the chapter will first explore the history of lawyers in Vietnam. It examines the different points of view and attitudes of governmental organisations and judicial organs towards legal practitioners. It then continues with a case study of the Nam Cam case- the largest and most infamous criminal case in Vietnamese legal history-to illustrate the shortcomings of the current legal reforms. The chapter concludes by arguing for further changes to secure the role of lawyers in judicial reform. 


\section{THE HISTORY OF LAWYERS IN VIETNAM}

\section{Prior to the August Revolution}

Lawyers, also known as thay cai ('defence counsel'), appeared in Vietnam with the French introduction of the court system (Nguyen Van Tuan 2001; Le Kim Que 2003). Before then, people only hoped for justice den gioi soi xet ('God willing') ${ }^{2}$ in feudal courts (Le Kim Que 2003). The feudal system did not recognise the role of defence counsel, especially under a Confucian social order which views the King as the son of God and the Mandarin as the parent-kings and mandarins did not accept the protestations of their people, their servants, or their children. In some dynasties, however, those who possessed certain legal knowledge occasionally helped people draft claims or advised them on petition or court procedures. Recent scholarship sees this as a preliminary form of the 'lawyer' profession (Tan Van Tai 2002), but it really only occurred on an ad hoc and unprofessional basis.

After the French colonial government conquered southern Vietnam in 1862, it established a French court to adjudicate French citizens (Le Kim Que 2003). Initially, lawyers had to be naturalised as French, but this restriction was gradually lifted to include Vietnamese who held French citizenship (Le Kim Que 2003). By 1884, when the French had colonised southern Vietnam completely and asserted their dominance over Central and North Vietnam, Vietnamese who held a Bachelor of Laws degree were permitted to practise as lawyers (Phan Huu Thu 2001). On 25 May 1930, the French colonial government issued an Order on the Establishment of the Bar Association that permitted bar associations in Hanoi and Saigon for the first time. This order officially recognised the existence of lawyers in Vietnam and provided that Vietnamese lawyers could appear before court if they

- held a Bachelor of Law degree

- had served at least five years' apprenticeship in a lawyers' office

- had passed the exam and been admitted to the bar association

- taken an oath to abide fully by the law and be loyal to the French government (Phan Huu Thu 2001).

Once accepted, these lawyers were allowed to open their own practice and receive clients.

It is self-evident that lawyers during the French colonial period had to respect the colonial government, as it was nothing but a replica of the homeland government. The laws implemented in southern Vietnam were transplanted French laws while those implemented in Central and North Vietnam were strongly influenced by French law (Durand 2002; Tran Thi Tuyet 2003; Nguyen Phan Quang and Phan Van Hoang 1995; Pham Hung 2000). This also explains the success of some lawyers in defending Vietnamese revolutionaries in the colonial courts (D.T. 2002). 


\section{After the August Revolution (1945-87)}

Immediately after occupying Northern Vietnam, the revolutionary government started to reorganise the judicial system. In October 1945, President Ho Chi Minh issued the Order on the Lawyer Organization. ${ }^{3}$ This order was the first document of the revolutionary government to recognise the existence and role of lawyers in the judicial system, representing a significant move towards compliance with the real situation in Vietnam at the time. Restrictions placed by the colonial government on the admission of lawyers to practise were loosened (Nguyen Van Tuan 2001; Phan Huu Thu 2001; Nguyen Dinh Loc 2001). The right of the defendant and the accused to present their case was established immediately after the first Order on Establishment of the Revolutionary Government Court was issued. ${ }^{4}$ These were important documents in the initial stage of the revolutionary government as they recognised the existence and necessity of lawyers in the revolutionary state apparatus.

The first Constitution of Vietnam reinforced this right by stating that it was an 'important democratic right of the accused' to be legally represented in criminal proceedings. ${ }^{5}$ Hence, it assumed the existence of a legal profession capable of fulfilling this task. Since Vietnam was a revolutionary state at that time, the safeguarding of this right proved to be a challenge for the new revolutionary government. Trained lawyers were mostly educated in the French legal system and had sworn allegiance to the French colonial government. However, some lawyers remained in Vietnam or returned from France and became members of the new Vietnamese government (Nguyen Phan Quang and Phan Van Hoang 1995; Pham Hung 2000). These lawyers made significant contributions to the rebuilding of Vietnam and also ensured that the legal profession continued to exist during the transition period. Still, there were not enough trained lawyers to ensure that all accused were legally represented and defended at trial, prompting President Ho Chi Minh to issue an order in 1949 that allowed those accused to nominate a citizen who was not a lawyer as defence counsel subject to approval by the chief judge. ${ }^{6}$ This led to the development of the new concept of bao chua vien nhan dan ('people's advocate'), very similar to that of certificat de citoyennet ('citizen certificate') during the 1798 French bourgeois revolution. At that time, the French Revolution abolished bar associations, arguing that citizens had the right to defence. In order to defend others, they only needed a certificat de citoyennet (see Le Kim Que 2003).

On 12 January 1950, the Ministry of Justice issued a decree providing details to President Ho Chi Minh's Order stating the conditions by which a citizen could become a people's advocate (Nguyen Van Tuan 2001): the person had to be a Vietnamese citizen, at least 21 years old, of good morality, with no prior criminal convictions. 
At the beginning of every year, the provincial resistance and administrative committees, together with the provincial chief judge, would develop a list—which the chief judge could alter at his discretion - of the qualified citizens who had agreed to appear as people's advocates before the court. This list would then be posted at the local court offices (Nguyen Van Tuan 2001). The incomes of lawyers and people's advocates differed - the people's advocate received an allowance from the court budget while lawyers received fees from the defendant or the defendant's relatives. ${ }^{7}$ Furthermore, people's advocates, unlike lawyers, had no obligation to pay personal income tax. ${ }^{8}$ Together these conditions ensured that poor people could access representation by defence counsel during court trials. This is possibly the most outstanding achievement of the revolutionary government in the initial stage.

People's advocates continued to exist and were further asserted through Circular No. 101/HCTP of the Ministry of Justice, 29 August 1957. Circular No. 101 clearly stated that 'While there are no adjustments to the "people's advocate" institution, the Order No. 69 dated 18 June 1949 and Decree 01/ND-NY dated 12 January 1950 on the "People's Advocate Organization" shall continue to be implemented' (Nguyen Van Tuan 2001:74).

After North Vietnam was liberated in 1955, the Vietnam Lawyers' Association (VLA) was established to encompass everyone working in the legal field. ${ }^{9}$ The association's membership therefore comprised not only lawyers but also people working within the legal sector at state institutions (Pham Hung 2000). Since the VLA's main purpose was to serve state policies (Pham Hung 2000) and to provide defence counsel if requested by the court, it cannot be regarded as comparable with a professional organisation like the bar association in Western legal systems.

The 1959 Constitution established the court and prosecutorial systems, and the Ministry of Justice was eliminated. The administrative judicial work, including the advocate's work, was assigned to the Supreme People's Court (Pham Hung 2000). A pilot law office, the Van phong Luat su Ha noi [Hanoi Lawyer Office], was established in $1963^{10}$ to ensure the constitutional right to defence. In its early years, the Hanoi Lawyer Office

- defended the accused in criminal cases and protected the legitimate rights of the parties in civil cases before the courts

- provided legal advice to the people and the cadres

- helped people draft petitions and other legal documents such as contracts and covenants

- contributed to legal propaganda through the court proceedings (Pham Hung 2000).

Despite the name 'Law Office', however, the organisation in fact comprised only people's advocates and operated as an administrative body under the direct administration of the Supreme People's Court (Phan Huu Thu 2001). The people's advocates were civil servants and received their salaries out of the state budget (Hanoi Bar Association 2002). It can, therefore, be said that in the period between 1960 and 1980, the legal profession virtually did not exist as it had been replaced by 
that of the people's advocates (Nguyen Van Thao 2001). Furthermore, people's advocates acted only in cases dealt with by the courts. In cases conducted by the Resistance, Administrative and Land Reform Committees, adjudicating matters where people protested against the revolution or were carrying out land reform, participation of the people's advocates was not necessary. The operations of those committees were indeed far more forceful than the courts (White 1981; Nicholson 2000). This caused Vietnamese society to perceive lawyers as limited only to criminal defence in court proceedings (Phan Huu Thu 2001).

The 1980 Constitution provided for the establishment of an organisation for lawyers, the first such provision since the revolution (Phan Huu Thu 2001; Nguyen Dinh Loc 2001). It was set up after the reunification of Vietnam and, taking into account the different habits of the people in the south of Vietnam-where people had long used lawyers to protect their rights in court—reaffirmed the defendant's right to defence as stated in the previous constitution. ${ }^{11}$ The new constitution thus formed the legal foundation to pass more laws with respect to the organisation of lawyers in Vietnam (Nguyen Van Tuan 2001; Hanoi Bar Association 2002:19) and harmonised the two systems of using lawyers' services.

After the Ministry of Justice was re-established, the management of lawyers was transferred from the government's Legal Committee back to the Ministry of Justice. ${ }^{12}$ The need to promulgate a legal document on the organisation of the legal profession began to take shape. Before issuing a legal document on the organisation of lawyers and defence work, the Ministry of Justice had to consult with the Supreme People's Court, the Supreme People's Procuracy as well as some other state authorities (Nguyen Van Tuan 2001). This legal document served as the legal foundation establishing a number of local doan bao chua vien nhan dan ('people's advocate organisations'). By the end of 1987, over 30 provinces and cities in Vietnam launched their own people's advocate organisations consisting of over 400 people's advocates. These continued to operate until the 1987 Ordinance on Lawyer Organisation was passed (Nguyen Van Tuan 2001).

\section{Following promulgation of the Ordinance on Lawyer Organisation (1987-2001)}

The Ordinance on Lawyer Organisation was enacted on 18 December 1987 and provided further details on lawyers' organisations. This ordinance was sought to revitalise careers as lawyers in preparation for the socioeconomic reform process in Vietnam (Nguyen Van Tuan 2001; Phan Huu Thu 2001). By 1989, 16 bar associations had been established, replacing the former people's advocate organisations (Nguyen Van Tuan 2001). To boost the establishment of local bar associations, the Ministers' Council (now called the 'government') issued on 21 February 1989 Decree No. 15/ HDBT on the Regulations of Bar Associations. The Ministry of Justice issued a document detailing this decree. ${ }^{13}$ Under these regulations, 61 bar associations with 82 branches had been set up by 30 September 2001, covering all provinces and cities in Vietnam. These bar associations comprise approximately 2100 practising lawyers (Nguyen Dinh Loc 2001; Nguyen Van Tuan 2001). 
Increasing professionalism is also reflected in the number of lawyers currently holding a university law degree. The figure increased from 60 per cent in 1989 to 85 per cent in 2001 (Nguyen Van Tuan 2001). The number of qualified judges and prosecutors, however, trails the figure for lawyers (Nicholson and Nguyen Hung Quang, forthcoming). ${ }^{14}$

The 1987 Ordinance on Lawyer Organisation has had limited success in changing people's attitudes towards the legal profession (Nguyen Van Thao 2001). In fact, the ordinance hindered lawyers' careers by stipulating governmental administrative control over lawyers (Nguyen Van Thao 2001). This control encompassed all aspects of lawyers' practice such as opening a legal practice and forming partnerships, thus denying activity, independence and freedom to practising lawyers (Nguyen Van Thao 2001; Nguyen Van Bon 2001). The practice of assigning cases and setting fees through the bar association's management serves further to restrict lawyers in their practice. The bar association charged an amount for the service depending on internal regulations (Nguyen Van Tuan 2001; Nguyen Van Bon 2001); and the practice essentially infringed citizens' right to choose their own lawyer, thus damaging public perceptions of lawyers (Nguyen Van Bon 2001).

In 1997, the Communist Party released a policy consolidating and strengthening the judicial assistance agencies, strongly emphasising the role of lawyers, legal consultancy and forensic examination..$^{15}$ These reforms were taken one step further in the 2001 Ordinance on Lawyers.

\section{From 2001 to the present}

The 2001 Ordinance on Lawyers has played an important role in the reform process of building a socialist state based on the rule of law. These reforms were meant to be implemented in depth and to include judicial reforms (Nguyen Dinh Loc 2001). This ordinance has considerably expanded lawyers' rights, addressing some of the shortcomings of the 1987 Ordinance. The 2001 Ordinance stipulates in more detail the scope of lawyers' practice, allowing them, for example, to practice independently or form partnerships with any number of members. ${ }^{16}$ Lawyers now may also establish joint ventures with foreign law firms under certain prescribed conditions. ${ }^{17}$ Moving beyond litigation, the ordinance is more attentive to the legal consultation of lawyers, particularly legal consultations on investment and business. To some extent, the 2001 Ordinance has enhanced lawyers' position, but in order to improve the social acceptance of lawyer's services it will be necessary to amend a number of procedural legal normative documents (Nguyen Dinh Loc 2001). The most significant change in the 2001 Ordinance was the recognition of the career as a lawyer as a professional career. Beside the provisions on organisation and professional practice, the 2001 Ordinance provides a mechanism to protect clients. ${ }^{18}$ All these changes have helped build public confidence in lawyers.

This is reflected in some statistics. Throughout the country, 2,360 lawyers have registered so far in 61 bar associations, practising in 680 legal offices, 45 branches and four law partnership companies. ${ }^{19}$ As of 30 September 2004, under the 2001 
Ordinance on Lawyers, approximately 26 per cent of these lawyers will be ineligible to practise law as they are civil servants, and 5 per cent will be rendered ineligible beyond the next five years because of their age.$^{20}$ However, taking into consideration the number of trainees enrolled in legal professional training schools-over 1,835 trainees in two years (2002-03 $)^{21}$ alone-it seems that the professional lawyer career is developing.

\section{ATTITUDE OF THE STATE AND THE PUBLIC TOWARDS LAWYERS}

Several factors shape how lawyers are perceived by society, such as certain characteristics of the state organisation, social features and legal institutions.

\section{Structure of the state}

Based on the comment of the former Minister of Justice Nguyen Dinh Loc that the 'lawyer career is a profession crucial to a democratic society', it would appear evident that lawyers can only function well in a democratic society. Resolution 8 mentioned the concept tranh tung dan chu ('democratic adversarial proceeding'), but no definition of this concept has yet been given. Nor has the question of whether this 'democratic' concept might be governed by the principle of 'democratic centralism' yet been answered. State agencies seem puzzled in implementing the principle in democratic adversarial proceedings; one document by the Ministry of Police states that lawyers, who are Communist Party members, must respect the adjudication directions of the Party in the adjudicating proceedings. ${ }^{22}$ This almost reflects the attitude of state agencies and officers towards the lawyers.

Lawyers are still not on equal footing with prosecutors in the democratic litigation process and administrative agencies are still not recognised appropriately in administrative procedures. This diminishes lawyers' role, confining it to the position of a sub-actor needed to perform a complete vo kich ('play').

\section{Structure of the society}

Agricultural society. Perhaps the primary reason for the lack of recognition of professional lawyers might be attributed to the fact that Vietnam is an agricultural country, with more than 80 per cent of its population living in rural areas. In these areas, perceptions of social order are still heavily influenced by Confucian ideology. Efforts to change that perception have been unsuccessful. The revolution of August 1945 dismantled the feudal regime, and the revolutionary government attempted to explain the new concept that state officers are day to cua nhan dan ('servants of the people'). Involvement of state officers is still avoided; instead, the guidance of decision-making bodies is followed.

In cases of dispute, recourse to alternative dispute resolution mechanisms is preferred. These mechanisms include amicable settlements, to hoa giai ('conciliation 
groups'), luat rung ('lynch law or self-justice'), or approaching senior officers in the administrative system. Courts are seen as the last resort to resolve a dispute.

Feudal ideology. Even though the August 1945 Revolution overthrew the feudal regime, the ideology upon which this regime had been based was much harder to eliminate from the people's thinking. State agencies and officers often refused to work with lawyers. In fact, many state officers were still influenced by feudal ideology (Nguyen Thanh Binh 2002). The mandarin-like behaviour of mal du siècle ('disease of the century'), or as it was popularly called, quan tinh, was considered appropriate under Confucian thought. ${ }^{23}$ This practice was often criticised by the Party. Although the Communist Party of Vietnam criticised feudal norms, in practice the principle of democratic centralism enabled a continuation of feudal thinking and relationships. Therefore, the attitude of revolutionary state officials, who considered lawyers as thay cai ('master of arguing', which did not facilitate an environment of mutual respect).

Legal history. Judicial inexperience also contributed to the population's general resentment of lawyers. The military and political influences affected not only lawyers but also the judicial system. This continued even after the revolutionary government took power.

The court was immediately considered one of the agencies serving the political agenda of the new government. From 1946 to 1954, the major task for the revolutionary government was to drive out the French colonisers. The Revolutionary Court was primarily a military-style court to adjudicate over soldiers who did not fully perform their duties, anti-revolutionary gangs, capitalists, feudalists and landlords. Quite often the judges had already made their decision before the hearing and the trial was only held for political purposes, which may explain the popular concept in Vietnam of an bo tu ('judgment already in the pocket') (Pham Hong Hai 2003). The defence counsel was often a cadre, a soldier of the Resistance Committee or the Administrative Committee, assigned by the court. The defence counsel's function guided by the higher officials and/or the judge. ${ }^{24}$ The role of the defence counsel was simply to demonstrate that the judgment of the Revolutionary Court reflected principles of democracy and fairness, while in fact they were only an integral constituent of the revolutionary adjudication system. Furthermore, the fear of being stigmatised for defending anti-revolutionary activists prevented defence lawyers from voicing dissenting opinions. The principle of tap trung dan chu ('democratic centralism') guided the operation of all agencies in the socio-political system. Therefore, defence counsel could not, or dared not, break this rule. Some defence counsel even refused to take up a case when the other party was a state agency (which often happened in the administrative cases). Even so, several lawyers accepted the role of defence subject to 'guidance' of a state agency or a court body. ${ }^{25}$ Contemporary experience with lawyers. Until the enactment of the Civil Code in 1996, contemporary laws had no provisions permitting lawyers to act as representatives of their clients before the administrative agencies. After the Civil Code was enacted, however, the state officers were still permitted only to work 
directly with the concerned parties. To be involved in the process, therefore, lawyers had to establish a relationship with the state officers. These relationships were called moi quan he tot dep ('good relationships') and included bribing state officers, and gave rise to the perception of lawyers as nguoi moi gioi ('the broker or middle man') or nguoi song ky sinh ('parasites'). ${ }^{26}$

\section{Judicial proceedings}

Lawyers' role in judicial proceedings is more clearly defined than their role before the executive agencies-their appearance demonstrating the new government's democratic characteristics but their actions ultimately serving revolutionary aims. In theory, decisions and judgments were considered to express the righteousness of the revolutionaries, represent the people's will, and were objectively and democratically rendered according to the principle of democratic centralism. Therefore, as a matter of practice, any act against the people's will would not be tolerated.

The role of lawyers in criminal proceedings illustrates this point. Their participation was confined to presenting their clients' case at court since they were not allowed to be involved in the investigation stages. ${ }^{27}$ The current Criminal Procedure Code allows lawyers to participate from the time the suspect is accused, except in special cases of extremely serious offences endangering national security where it is necessary to keep the investigation secret. ${ }^{28}$ In reality, however, the investigative agency, the court and the prosecution have often denied lawyers the right to participate in the investigative stage, and there is no record so far of any cases where lawyers were allowed to participate in the investigative process, except for juvenile cases where it was essential that a lawyer was involved in order to provide a signature for completion of the case file. ${ }^{29}$ If a lawyer wants to participate in the investigation process, a good relationship with the prosecution is vital. The absence of lawyers in most cases creates opportunities for the investigative body and the prosecution to handle the file alone, and this lack of oversight opens the potential for investigators and prosecutors to become 'subjective, or even sometimes, negative enough to distort the case file'.$^{30}$ In many cases defendants have declared during court hearings that they were 'induced or coerced to give testimonies', ${ }^{31}$ placing the court in the difficult position of deciding whether these claims were true. This seems to be one of the reasons for many 'wrongfully decided' cases in Vietnam.

There are several practical restrictions on lawyers when a case comes to trial. First, a lawyer needs an introductory letter from the bar to gain access to the criminal file. Second, access to the file is only granted when it is not needed by a panel member. Third, a lawyer is not allowed to photocopy the case file, but is permitted only to take notes of the important points. In complicated criminal cases, it can often take days for a lawyer to go through the file. Finally, if a lawyer wants to meet the client in a detention camp, another introductory letter, this time from the court or the bar, is required. All these aspects form a part of the xin cho ('beg and give') practice in criminal proceedings. 
At the hearing, the lawyer has the right to express his opinions to defend his client. However, such opinions are rarely respected by the trial panel or recorded in the judgment. In reality, the conclusion of the judgment, or sometimes the entire judgment, is often written beforehand and contains only the opinions of the prosecutor as expressed in the indictment and offered to the trial panel. The defence lawyer's opinions are summarised in one or two lines in the judgment ${ }^{32}$ or only with the phrase 'after hearing the lawyer's opinions'.

This contributed to the development of a particular style for the speeches of the defence counsel

- admitting that the prosecutor's accusation is correct

- analysing the causes to show that the defendant committed the crime

- presenting some mitigating elements on behalf of the defendant

- suggesting that the trial panel mitigate punishment of the defendant.

This structure is widespread, especially among older lawyers. ${ }^{33}$

The factors discussed above meant that the majority of citizens did not fully understand what the functions of lawyers were in criminal proceedings. Some viewed lawyers as government officials and therefore believed that they were of limited help since they would adopt a similar attitude to that displayed by governmental agencies. People who possessed some legal knowledge, or who were involved in court cases, knew that lawyers only had a limited function as a nguoi moi gioi ('broker'). Thus, before seeking a lawyer's services, many people resorted to their quan he ('relationships') to settle the case. Many business entities, especially staterun enterprises, rarely used lawyers in their business affairs, preferring instead to take advantage of administrative interrelationships among the line agencies, or the privileges of a state agency, to support or defend their case. Moreover, lawyers were seen to complicate the case unnecessarily and annoy state officials.

Law graduates also prefer not to become lawyers directly after graduation. Most graduates want to work in secure jobs in governmental institutions. This is the common attitude among graduates in the bao cap ('government subsidy') period of a centrally planned economy. Only those graduates who could not find jobs in government institutions would reluctantly accept a position as a lawyer. ${ }^{34}$ Even then, acting as a lawyer is regarded as a temporary job while waiting for a position in a government institution.

Since the education of lawyers falls short in the area of practical experience-no training courses in professional skills existed until a pilot one-week course was held by the Ministry of Justice in 1996-a lawyer has to develop these skills alone. ${ }^{35}$ This is a significant difference from other legal professionals where training courses were held and funded countrywide. Two years after the pilot course, the Asian Development Bank provided funds for the Ministry of Justice to establish a 3-month comprehensive professional training courses for lawyers. The newly-established Legal Professional Training School ${ }^{36}$ has held three professional skills training courses for lawyers in the last two years (2002-03). The training courses run for six 
months and are expected to equip the trainees with good theoretical knowledge. However, they fail to reflect or address the difficulties and challenges that lawyers may face in practice.

According to the Legal Needs Assessment Report for Vietnam for 2002-10, Viet Nam needs 17,000 to 18,000 lawyers by $2010 .{ }^{37}$ Unfortunately, the basis for this assessment is not known, but if these numbers are correct it is vital that the attitude towards the role and activities of lawyers in the judicial system is changed in order to attract lawyers to a career as practicing lawyers.

Resolution No. 08-NQ/TW of the Politburo on Forthcoming Principal Judicial Tasks has laid foundations for judicial reforms. In particular, for the first time, an important document of the Central Communist Party and the state requires the legal systems 'to ensure democratic pleading with the barristers and the people's advocate'. ${ }^{38}$

It can bee seen that some important improvements have been made during the law reform process, at least on paper.

\section{THE 'NAM CAM' CASE ${ }^{39}$}

The Nam Cam trial tested the recent law reforms. This case study illustrates the shortcomings and improvements of the recent legal reforms, highlighting the discrepancies between the official Party line and the perception of the population with respect to the effectiveness of the legal system.

The case of Truong Van Cam is considered the biggest case in the history of criminal procedures in Vietnam. ${ }^{40}$ This is not only because of the high number of defendants involved in the case-about 155, compared to the 77 defendants in Tang Minh Phung's criminal case in 1999 and 74 defendants in Tan Truong Sanh's case in $1999^{41}$ — but also because of its far-reaching implications.

The trial tested the judicial system in two ways. First, it tested the seriousness and commitment of the Party to crack down on corruption within the Party and police. Therefore, if the Party was seriously committed to changes, it should have interfered less with the prosecution of officials. Crime and graft are two of the major problems investors are facing in Vietnam. The vicious circle of corruption is spurred on by civil servants' low wages and a bureaucratic legal system that encourages businesses 'to cut corners by offering bribes' (Maria 2003:n.p.).

Second, the trial tested the recent reforms with respect to the close nexus between the state and the Party. The question was whether the judges would utilise the changes in the legal system and thus withstand political pressure. According to the presiding judge Bui Hoang Danh, 'it was a public and democratic trial, in line with legal reforms' (Judge Bui Hoang Danh, cited in Cohen 2003b:A4). The trial has been further praised for the improvement of the rights of the defendant. Among other things ${ }^{42}$ the court showed an unprecedented willingness to grant defence lawyers the right to express their opinion and the right to have access to their clients before the trial (Cohen 2003b). 
In general, the criminal case against Nam Cam contains all the elements of a good Mafia criminal story and reads like Mario Puzo's novel 'The Godfather'. ${ }^{43}$ When Nam Cam was arrested in December 2001, the charges brought against him did not foreshadow the ultimate scandal. One of Nam Cam's gang members had incurred an illegal gambling debt and left a car as collateral. The car's licence plate, however, was fake, and the resulting search for the owner pointed to Nam Cam (Vasavakul 2003). The subsequent investigation resulted in a mass arrest of 155 accomplices.

\section{Criminal history of Nam Cam}

Truong Van Cam has a long-standing criminal record. Owing to the intervention of corrupt state officials such as police, prosecutors and Party members, however, he had persistently been able to avoid arrest and prosecution (Quinn 2003).

According to his police file, he was sentenced to a 3-year prison term for stabbing a man to death when he was 15 years old (Rowse 2003a). ${ }^{44}$ His career path afterwards included working at the docks and joining the South Vietnamese army, but after the reunification he started to rise through the criminal ranks to become a feared Mafia boss..$^{45}$ The three arrests for gambling charges between 1978 and 1982 appeared trivial compared with what was to come. In 1995, army intelligence was alarmed by Nam Cam's criminal activities and a report was given to Prime Minister Vo Van Kiet. ${ }^{4}$ He was sentenced to a 3-year prison term in a re-education camp for his connections to the so-called xa hoi den ('black societies') and his money-lending practice. ${ }^{47}$ By then, however, Nam Cam had already established a close network with Party officials ${ }^{48}$ and was able to secure an early release eight months ahead of schedule (Thayer 2002).

\section{The trial}

In December 2001, Nam Cam was arrested along with 155 associates. The trial proved to be an unprecendented logistical exercise. In preparing for the trial, the Ho Chi Minh City People's Court spent billions of dong (VND) to upgrade trial facilities. ${ }^{49}$ In order to reflect the recent law reforms, the Ho Chi Minh City People's Court established an adjudication group of six judges (four principal judges and two on standby), five people's assessors, and three court secretaries (two principal and one standby). ${ }^{50}$ The paperwork of the trial was immense; the case dossier consisted of 118 volumes (20,000 pages in all), a 600-page indictment (colour-printed for the first time) distributed to all the lawyers and defendants, and a 400-page prosecutorial conclusion (The Gia 2003). ${ }^{51}$

The hearing of the Nam Cam case took 57 working days, with 83 lawyers participating for the defence, and 238 summoned individuals. ${ }^{52}$ Over 300 police officers were mobilised to preserve order at the court proceedings.

\section{Experience of lawyers during the trial}

Lawyers experienced several improvements in their working conditions in preparation for and during the trial. With respect to preparation for the trial, the 
meetings between clients and their lawyers were less restricted. The lawyers had access to the files and were given copies of the indictment free of charge..$^{53}$

The most significant improvements, however, were during the trial. Defence counsels were allowed to express their opinions without any interruption. Other activities allowed for the first time in a Vietnamese court hearing were that

- defence lawyers were allowed to use secretaries in the court hearing

- defence lawyers were allowed to use pictures and tape recorders to illustrate evidence before the court

- defence lawyers were given the opportunity to present their case with more freedom and without the typical interruption or silencing by judges

- defence lawyers asked for adversarial opinions of the prosecutor at the hearing in order to determine the objective facts. ${ }^{54}$

The question of whether the defence counsel really had a position equal to the prosecutor during the proceedings can only be answered by studying the experience of Dang Van Luan.

Dang Van Luan was the defence lawyer for Tran Mai Hanh, a former member of the Central Communist Party and former state radio chief who was accused of receiving bribes and disclosing state secrets. In the first days of the hearing, the proceedings were conducted without any startling events, but during the pleading procedure the defence counsel boldly stated that his client was innocent, that the charges brought against Tran Mai Hanh were 'vague, unsubstantiated and unpersuasive' and that the 'police had orchestrated gangsters' testimony in prison rehearsals' (Cohen 2003a:22). The prosecutor's case indeed included some contradictions and gaps, the witnesses could not remember the location of Hanh's office nor specify when and where Tran Mai Hanh was allegedly bribed. Defence Attorney Luan requested clarification of these points by the prosecution office but the prosecutor refused. ${ }^{55}$

Dang Van Luan's comments in court sparked a public debate about the appropriate behaviour in court of defence attorneys. The press was divided in its opinion about Luan's comments, either finding it lam dung quyen dan chu (an 'abuse of the democratic right') or supporting the lawyer's freedom of speech. ${ }^{56}$ It also showed the far-reaching consequences such behaviour could generate. The prosecutor of Tran Mai Hanh's case commented that Dang Van Luan's behaviour 'offended the agencies conducting the proceedings' and referred to a provision of the Criminal Procedure Code, asking the presiding judge to prosecute the defence counsel at the hearing. ${ }^{57}$ The Ministry of Police asked several official bodies ${ }^{58}$ to initiate disciplinary proceedings against Dang Van Luan. ${ }^{59}$

Dang Van Luan protested against these accusations, saying that he had not deliberately offended or slandered the judicial agencies; he had just performed the thien chuc ('heavenly mandate') and the su menh ('mission') of a barrister ${ }^{60}$ and condemned the actions by the prosecution office as gay ap luc ('applying pressure'). ${ }^{61}$ He was supported by the chairman of the Hanoi Bar Association Nguyen Trong Ty who said that 'lawyers have the right to argue, to defend their clients' and that there was 'no reason to have a police investigation [of Luan]' (Cohen 2003a:23). 
However, the judgment did not take Luan's arguments into consideration. Instead, they were regarded as suy luan chu quan ('subjectively deduced') (2) $^{6}$ and thus irrelevant. ${ }^{63}$ The imposed sentence was therefore close to the sentence sought by the prosecutor.

Thus, lawyers were willing to utilise recent law reforms and establish a more involved and active role in criminal proceedings, but these attempts fell short since the prosecution and the court rejected these efforts and resumed their 'old ways'.

Dang Van Luan's experience in particular shaped public opinion of the Nam Cam trial. It was noted that defence lawyers had more freedom to conduct their defence, and was read as a sign that less political restriction was placed on lawyers than in the past. But the case also raised questions as to whether the current reforms went far enough (Tran Dinh Thanh Lam 2003).

\section{Public response to the case}

Daily press conferences, extensive press coverage in the newspapers and live television broadcast throughout the trial brought public attention to the trial. People from all social classes attended the public hearings. This exposure affected the way the public viewed the recent reforms to the legal system and the anti-corruption campaign. While the state and Party aimed to show their commitment to these changes, the public's perception of the Nam Cam affair was split. The trial initiated the recent law reforms and pointed out the urgency for law reforms (Quinn 2003). It also secured Party commitment, albeit circumscribed, to crack down on corruption.

The public, however, questioned this commitment during the trial. Neither foreign nor local observers were satisfied with the depth of the investigation. While speculation about the guilt of the charged Party officials was limited, most people saw them as just scapegoats to a very widespread problem, sacrificed in a trial that appeared '....more to do with competing factions and power bases among senior party members than anything else' (Rowse 2003e).

A television talk show broadcast the night before the verdict was delivered featured a discussion about a new anti-corruption movie, Luoi Troi ('Heavens Net'), that confirmed this impression. Apparently reflecting reality, the movie showed Party officials and business linked in a web of corruption, only its lesser criminal characters being convicted while the mastermind, a Party official, walks free. This caused one talk show participant to raise the question of whether the recent anticorruption campaign targeted the 'tigers' or the 'cats' (Cohen 2003a:23).

Evidence given during the trial supports this speculation. Party officials appeared to have been bought by minimal bribes, even by Vietnamese standards ${ }^{64}$ probably in order to avoid the harsh punishments of the new anti-corruption law (Cohen 2003c). It is not surprising, therefore, that none of the government-linked defendants received death sentences (Chicago Tribune, 15 September 2003). 


\section{CONCLUSION}

The Nam Cam trial illustrates the contradictions of the recent law reforms. On the one hand, improvements have been made with respect to the rights of the defendant and the participation of defence lawyers in the course of the trial. These recent changes have not yet been adopted and incorporated by other legal parties such as the judges and the prosecution. In fact their attitude and behaviour towards lawyers has not undergone significant changes. This is reflected in the public's perception of the criminal justice system, which has not significantly improved. The public still views the legal system as unequipped to address the criminal activities of Party officials and views lawyers as still restricted by political constraints.

In order for reforms to be more effective, significant changes in the judicial system are necessary; not only the position of lawyers but all parts of the judicial system need to be strengthened. This would enhance the effectiveness of judicial activities and reduce the phenomenon of may moc, don thuan, vo chinh tri ('mechanical and simple legalism, non politics') in the judiciary (Nguyen Van Hien 2001).

The motive behind such improvements is not only internal as Vietnam is preparing for accession to the WTO. Lawyers are especially equipped to inspire and strengthen judicial reforms and contribute to an independent and transparent justice system.

\section{NOTES}

1 Resolution 8, On Forthcoming Principal Judiciary Tasks, Communist Party Politburo, 2 January 2002.

2 Den gioi or den troi means 'God's light'; Soi xet means 'considering'; Den gioi soi xet means 'God will consider the case' or 'God willing'. Perhaps this idiom appeared as a reflection of people's expectations of the human courts in the past.

3 Order No. 46/SL of President Ho Chi Minh on Lawyer Organisation, 10 October 1945. Available from the law database of the National Assembly Office.

4 Order on Army Court Organisation, 15 September 1945, law database of National Assembly Office. See also Nguyen Van Tuan (2001).

5 Article 67, Constitution of Vietnam 1946. See also Nguyen Van Tuan (2001).

6 Order No. 69-SL of President Ho Chi Minh on Permission of Accused Requesting a Citizen who is not a Lawyer to Defend before Ordinary Courts and Special Courts, 18 June 1949.

7 Article 3, Order No. 69-SL (1949).

8 Part B, Order No. 49-SL on Direct Tax, 18 June 1949.

9 The Vietnam Lawyers' Association was established on 4 April 1955.

10 According to Nguyen Van Tuan (2001), the 'Law Office' was established in 1963, but the Hanoi Bar Association (2002) claims that it was established in 1965.

11 Article 133, Constitution of Vietnam 1980.

12 The Legal Committee was established in 1972, and the Supreme People's Court transferred the Lawyer Office to this committee in 1974. Decree 143/HDBT of the Government on Functions, Tasks and Powers of Ministry of Justice, 22 November 1981.

13 Circular 313/TT/LS of Ministry of Justice, 21 February 1989, providing guidelines for Decree 15/HDBT on Regulations of Bar Associations. 
14 Ho Chi Minh City Legal Newspaper (No. 52/2003, 17 July 2003) disclosed that only 48 per cent of prosecutors have a Bachelor of Laws degree. See also Pham Hong Hai (2003).

15 Nghi quyet Hoi nghi lan thu ba Ban chap hanh Trung uong Dang Cong san Vietnam [Resolution of the Third Meeting of Vietnam Communist Party Central Committee], Communist Party Central Committee, September 1997.

16 Article 15, Ordinance on Lawyers 2001.

17 Article 22, Ordinance on Lawyers 2001.

18 Articles 16, 23, 25, 29 and 41, Ordinance on Lawyers 2001.

19 Pers. comm. with various lawyers and the Legal Consultancy Department, Ministry of Justice.

20 Pers. comm. with various lawyers and the Legal Consultancy Department, Ministry of Justice.

21 Content from the Legal Professional Training School Update, October 2003.

22 Official letter 071/C16, Ministry of Police, 14 May 2003.

23 Quan tinh is also translated as 'red tape' by the Legislative Studies Magazine (No. 5/2002, English summary, p 83); English Index of Article Published in 2002, Special Issue No. 2, January 2003. The author, Nguyen Hung Quang, prefers the translation of 'mandarin-like behaviour' because it is more comprehensive.

24 Order 217/SL of President Ho Chi Minh dated 22 November 1946 on laying down mechanism of judges becoming lawyers.

25 See, for example, the article 'Luat su voi nhung ap luc "vo hinh" [Lawyers with invisible pressures]', Sunday Legal Newspaper, No. 166, 13 June 2003:7.

26 The author, Nguyen Hung Quang, heard this description in 2000 from a client when discussing the role of lawyers in society.

27 'Luat su chua duoc tao dieu kien de thuc hien quyen bao chua [Lawyers have not created adequate conditions for performing defence work]', Vnexpress, 18 August 2001. Available online at http://vnexpress/vietnam/phapluat. The 2003 Criminal Procedures Code passed by the National Assembly in November 2003, however, accepted lawyers' participation in the investigation stage but had not come into force when this chapter was completed.

28 Article 36, Criminal Proceedings Code.

29 'Luat su chua duoc tao dieu kien de thuc hien quyen bao chua' [Lawyers have not created adequate conditions for performing defence work]', Vnexpress, 18 August 2001. Available online at http://vnexpress/vietnam/phapluat.

30 'Luat su chua duoc tao dieu kien de thuc hien quyen bao chua [Lawyers have not created adequate conditions for performing defence work]', Vnexpress, 18 August 2001. Available online at http://vnexpress/vietnam/phapluat. See also Pham Hong Hai (2003:34, 38).

31 'Luat su chua duoc tao dieu kien de thuc hien quyen bao chua [Lawyers have not created adequate conditions for performing defence work]', Vnexpress, 18 August 2001. Available online at http://vnexpress/vietnam/phapluat.

32 'Bai bao chua-dau phai kieu gi cung duoc', ('Argument Speech-Not Any Form Is Acceptable?'), Ho Chi Minh City Legal Newspaper No 65/2003, 1 September 2003, p. 7.

33 This claim is based on anecdotal evidence noted by Nguyen Hung Quang, a barrister in Hanoi, after he participated in numerous hearings where the old barristers provided arguments of this structure.

34 I base this opinion on my time studying at the Hanoi Law University. Of the 700 graduates in 1996 from the Hanoi Law University, only about 40-50 work as private lawyers.

35 In 20-25 November 1996, the Ministry of Justice organised a training course for lawyers in the Northern area. A similar course was also organised in the Southern area in December 1996 for about 100 lawyers.

36 The Legal Professional Training School was established by Decision 34/1998/QD-TTg of the Prime Minister, 11 February 1998.

37 Legal Needs Assessment on Vietnam Legal System 2001-2010, Item 6.6.

38 Item b, section 1, Part B, Resolution No. 08-NQ/TW of the Politburo on Forthcoming Principal Judicial Tasks, dated 2 January 2002.

39 The popular name of the case 'Nam Cam' derives from the nickname of Truong Van Cam, the defendant, which is 'Nam Cam' or 'Fifth Orange'.

40 This heading was the title of many articles about Nam Cam case in Phap Luat newspaper.

${ }^{41}$ See http://www.laodong.com.vn/sodara/0599/24/thoisu/blsk.htm [accessed 16 September 2003]; and http://www.laodong.com.vn/sodara/1199/17/thoisu/ct.htm [accessed 16 September 2003]. 
42 For further details on the improvements, compare the section 'The experience of lawyers during the trial' below.

43 The association of Truong Van Cam with 'The Godfather' has been made by several authors such as Cohen (2002:56); Mills (2003); and 'Appeal for Vietnam Mafia boss and Party cadres set for September 15', Agence France Press, 13 August 2003.

44 See also Indictment of Truong Van Cam and Associates, p. 377.

45 Indictment of Truong Van Cam and Associates, p. 24. See also Cohen (2002).

46 Indictment of Truong Van Cam and Associates, p. 10; see also Rowse (2003a).

47 Indictment of Truong Van Cam and Associates, p. 24; see also Vasavakul (2003).

48 In the wake of the 'Nam Cam' case, the two senior Party members, Tran Mai Hanh and Pham Sy Chien, were found guilty of securing Nam Cam's early release in return for cash and gifts (Rowse 2003c).

49 Nhan Dan Newspaper website, http://www.nhandan.org.vn, visited 13 June 2003.

50 Quang Chung (2003); and 'Khai mac phien toa xet xu vu an hinh su lon nhat tu truoc toi nay [Opening of biggest criminal trial from the time before to now]', VnExpress. Available online at www.vnexpress.net [accessed 25 February 2003].

51 'Nam Cam trial flags state's fight against serious crime', The Vietnam Investment Review, 10 March 2003

52 Stories conflict on how many people were summoned. According to http//vnexpress.net/ legal.html, there were 238 related persons, but the Nhan Dan Newspaper website, http:// www.nhandan.org.vn, reported that there were 253 related persons.

53 This was a significant difference because, as noted earlier, lawyers previously had to take notes in court office.

54 See 'Phong cach bao chua cua luat su Luan va luat su Tri [Defending the methods of lawyer Luan and lawyer Tri]', Ho Chi Minh City Legal Newspaper, 15 May 2003:10; 'Nay sinh cac van de phap ly [Arising Legal Issues]', Sunday Legal Newspaper, No. 118, 18 May 2003:11; 'Khac nhau ve ap dung luat? [Different application of law?]', Sunday Legal Newspaper No. 124, 25 May 2003:11; 'Minh hoa tai toa, duoc khong? [Demonstrating and illustrating in the hearing, can be done?]', Ho Chi Minh City Legal Newspaper, 8 May 2003:7.

55 'Tranh luan voi cac luat su, cong to vien phat bieu "bao chua xuc pham co quan to tung la to ra bat luc truoc viec chung minh than chu cua minh vo toi"' [Argument with defence counsels, the prosecutor's speech on defence aiming to offend the judiciary bodies that manifests itself as helpless in the face of the demonstration of innocence of the clients]', Phap Luat Newspaper, 21 May 2003:11. Several defence attorneys were faced with a similar problem but in most cases these concerns were not addressed by the prosecution office ('Nhung cau noi an tuong trong tranh luan [Some impressive words in the pleading section]', Phap Luat Newspaper, No. 124, 25 May 2003:11; 'Vien kiem sat khong tranh luan co nghia la dong y [Procuracy refused to argue the meaning of "consent"]', Vnexpress, 22 May 2003.

56 'Phong cach bao chua cua luat su Luan va luat su Tri' [Defending methods of lawyer Luan and lawyer Tri]', Ho Chi Minh City Legal Newspaper, 15 May 2003:10; 'Tran Mai Hanh khong pham toi [Tran Mai Hanh has not been found guilty]', Ho Chi Minh City Legal Newspaper, 13 May 2003:11.

57 'Vien kiem sat de nghi khoi to luat su Dang Van Luan' [The procuracy requests to bring barrister Dang Van Luan To Trial]', Vnexpress, 20 May 2003.

58 Official letters were send to the Ho Chi Minh City People's Court, the People's Procuracy, The Ministry of Justice, the trial panel and the Communist Party Committee, since Dang Van Luan was a Party member.

59 'Luat su Dang Van Luan da vu khong co quan dieu tra [Barrister Dang Van Luan has slandered the investigation body]', Vnexpress, 16 May 2003; Official Letter 071/C16 of Ministry of Police, 14 May 2003; Official Letter No 071/C16 of Ministry of Police, 14 May 2003.

60 'Luat su Luan bao luu toan bo y kien cua minh [Barrister Luan sticks to his argument]', Vnexpress, 22 May 2003; 'Toi khong mat sat co quan dieu tra ma chi lam dung thien chuc luat su' [I did not slander the investigation body, only perform heaven mandate of lawyers]', Vietnam News Agency; 'Luat su Dang Van Luan: "Vai nam nua du luan se phan quyet chuyen nay" [Barrister Dang Van Luan said: some years later public opinions will judge this issue]', Ho Chi Minh City Legal Newspaper, No 46/2003, 26 June 2003:7; 'Luat su va co quan to tung phai ton trong nhau, Doan Luat su Thai Binh rut kinh nghiem sau vu an Nam Cam [Lawyers and judicial bodies should respect each other]', 'Thai Binh Bar Association holds a meeting to study the experience of the Nam Cam Case]', Phap Luat Newspaper, 21 July 2003:5. 
${ }^{61}$ 'Luat su Luan bao luu toan bo y kien cua minh [Barrister Luan sticks to his argument]', Vnexpress, 22 May 2003.

62 In the wake of the Nam Cam trial, the Ministry of Justice requested that all bar associations with members participating in the trials conduct further training of the defence lawyers in order to develop their skills and avoid the accusation of 'subjective deduction'. However, most bar associations took the opportunity to request from state agencies as well as the courts that their independence and professionalism should be respected. This is clear evidence of the professional pride and attitude of these associations ('Luat su va co quan to tung phai ton trong nhau, Doan Luat su Thai Binh rut kinh nghiem sau vu an Nam Cam' [Lawyers and judicial bodies should respect each other, Thai Binh Bar Association holds a meeting to study the experience of the Nam Cam case], Phap Luat Newspaper, 21 July 2003:5).

63 'Hau het cac lap luan cua luat su trong vu an Nam Cam bi bac bo [Most arguments of defence counsels in Nam Cam hearing were rejected]', Vnexpress, 4 June 2003.

64 Former radio chief Tran Mai Hanh, who assisted Nam Cam's criminal career, particularly by securing his early release from re-education camp in 1997, allegedly received US\$6,000 and an Omega watch (Cohen 2003b).

\section{REFERENCES}

Cohen, M., 2002. 'Murder and mystery', Far Eastern Economic Review, 165(56):56-58.

— 2003a. 'Crime fighting for the masses', Far Eastern Economic Review, 19 June, 166(24):22-23.

_ 2003b. 'Rare move targets gangs, protectors in government', The Asian Wall Street Journal, 6 June:A4.

_ 2003c. 'Vietnam crime figures receive death penalty', Asian Wall Street Journal, 6June:A4.

D.T., 2002. 'Khi luat su vung tay [When the lawyer swings his arm]', Laodong Newspaper, 189:n.p. Available online at http:/ / www.laodong.com.vn [accessed 8 June 2003].

Duc Uy-Duc Dung, 2002. Bi an tam ly nguoi Vietnam [Secrets of the Mental Habits of the Vietnamese People], People's Police Publishing House, Hanoi.

Durand, B., 2002. 'Cac luat gia Phap va van de phap dien hoa o Vietnam-vi du ve luat to tung dan su nam 1918 [French lawyers and law development in Vietnam]', Foreign Researchers Discussing Vietnam, Volume 1, The Gioi Publishing House:91105.

Hanoi Bar Association, 2002. Lich su Doan Luat su thanh pho Ha Noi (1984-2002) [History of the Hanoi Bar Association from 1984-2002], Hanoi Bar Association, Hanoi.

Hoang The Lien, 2002. Quan diem cua Dang va Nha nuoc ve cai cach tu phap tu nam 1986 cho toi nay [The Point of View of the Communist Party and State on Judicial Reform from 1986 until Now], conference paper presented at 'The Points of View on Judicial Reform in Circumstance of Building Up Socialist Law-based State of the People, by the People and for the People' Conference, Ministry of Justice, Hanoi.

Kazim, A., 2003. 'Vietnam's top gangster found guilty of murder and bribery', Financial Times, 5 June: 12. 
Le Kim Que, 2003. 'Nguon goc nghe luat su [Origin of the lawyer career]', Lawyer Today Magazine, 11 September.

Lindsey, T., 2002. 'History always repeats? Corruption, culture and "Asian values"', in T. Lindsey and H. Dick (eds), Corruption in Asia: rethinking the governance paradigm, Federation Press, Sydney:1-23.

Maria, K., 2003. 'Vietnam: death sentence upheld for "Nam Kam"', Voice of America News, 30 October 2003. Available online at http: / www.voanews.com/english/ Archive/a-2003-10-30-40-Vietnam.cfm [accessed 10 January 2005].

Marr, D., 2000. 'Concepts of 'Individual' and 'Self' in Twentieth-Century Vietnam', Modern Asia Studies, 34(4):769-96.

Mills, E., 2003. 'Crime boss faces execution as Vietnam's government tries to resurrect its legitimacy', World Markets Research Centre Daily Analysis, 30 October

Nguyen Dang Thuc, 1992. Lich su tu tuong Vietnam [History of Vietnamese Ideologies], Ho Chi Minh City Publishing House, Ho Chi Minh City.

Nguyen Dinh Loc, 2001. 'Ve Phap lenh luat su 2001 [Comments on the Ordinance on Lawyers 2001]', Legal and Democratic Magazine, Special Issue for the Ordinance on Lawyers 2001:6-17.

Nguyen Ngoc Huy and Ta Van Tai, 1986. 'The Vietnamese text', in M.B. Hooker (ed.), Laws of South-East Asia, Volume 1, Butterworths, Singapore:435-96.

Nguyen Phan Quang and Phan Van Hoang, 1995. Luat su Phan Van Truong [Lawyer Phan Van Truong], Ho Chi Minh City Publishing House, Ho Chi Minh City.

Nguyen Thanh Binh, 2002. 'Quan tinh va xoa bo quan tinh [About "red tape" and how to kill it]', Legislative Studies Magazine, 5:6.

Nguyen Van Bon, 2001. 'Hinh thuc to chuc hanh nghe luat su theo Phap lenh Luat su 2001 [Forms of legal practising organizations according to the Ordinance on Lawyers 2001]', Legal and Democratic Magazine, Special Issue for Ordinance on Lawyers 2001:61.

Nguyen Van Hien, 2001. 'Thuc trang doi ngu tham phan o Vietnam va phuong huong doi moi trong thoi ky moi [Judicial criteria: current situation and requirements for new era]', People's Court Journal, 4:2-6.

Nguyen Van Thao, 2001. 'Mot so van de can quan tam khi thi hanh Phap lenh Luat su [Several concerns when the Ordinance on Lawyers is implemented]', Legal and Democratic Magazine, Special Issue for the Ordinance on Lawyers 2001:26-37.

Nguyen Van Tuan, 2001. 'Su hinh thanh va phat trien nghe luat su o Vietnam [Formation and development of the lawyer career in Vietnam]', Legal and Democratic Magazine, Special Issue for the Ordinance on Lawyers:38-46.

Nicholson, P., 2000. Borrowing Court Systems: the experience of the Democratic Republic of Vietnam, 1945-1976, PhD thesis, University of Melbourne, Melbourne.

, 2002. 'The Vietnamese court and corruption', in T. Lindsey and H. Dick (eds), Corruption in Asia: rethinking the governance paradigm, Federation Press, Sydney:201-18. 
and Nguyen Hung Quang, 2005. 'The Vietnamese judiciary: the politics of appointment and promotion', Pacific Rim Policy Journal, 14(1):1-32.

Pham Hong Hai, 2003. Mo hinh ly luan Bo luat to tung hinh su Vietnam [Theoretical Model of the Criminal Procedures Code of Vietnam], People's Police Publishing House, Hanoi.

Pham Tri Thuc, 2002. 'Ve Du an Luat To chuc Vien Kiem sat nhan dan sua doi [About the Project of Amendment of Law on the Procuracy Organization]', Legislative Magazine, No.2

Pham Hung, 2000. Speech at 45 Year Establishment Anniversary of the Vietnam Lawyers Association, The Summary Record of 45 Year Anniversary, Vietnam Lawyers Association, Hanoi.

Phan Huu Thu, 2001. 'Dao tao, boi duong luat su trong thoi ky doi moi [Training and professionally improving the lawyer career in the Doi Moi period]', Legal and Democratic Magazine, Special Issue for the Ordinance on Lawyers 2001:92102.

Quang Chung, 2003. 'Giant criminal ring to stand trial on February 25', The Saigon Times Daily, 20 February.

Quinn, B., 2003. 'Vietnam's continuing legal reform: gaining control over the courts', Asian Pacific Law and Policy Journal, 4(12):431-68.

Rowse, B., 2003a. 'Game over for defiant Vietnam crime boss', Agence France Presse, 5 June.

—, 2003b. 'Vietnam crime boss fighting for his life', Agence France Presse, 4 June.

— 2003 c. 'Vietnam Mafia boss found guilty as Communist Party corruption exposed', Agence France Presse, 4 June.

_ 2003d. 'Vietnam ousts top Communist Party cadres over Mafia scandal', Agence France Presse, 15 July.

_ 2003e. 'Vietnam's explosive corruption showtrial reaches scripted climax', Agence France Presse, 5 June.

Tan Van Tai, 2002. 'Phap quyen trong phap luat truyen thong cua Vietnam va Trung quoc co-tap tuc phap ly Dong A truyen thong duoi anh sang cua cac chuan muc phap quyen hien dai [Rule of law in traditional legislation of ancient Vietnam and China: traditional legal customs of East Asia in the light of modern rule of law standards]', Foreign Researchers Discussing Vietnam, Volume 2, The Gioi Publishing House, Hanoi:424-46.

Thayer, C.A., 2002. Recent Political Developments: Vietnam in 2002, Paper presented at the Vietnam Update Conference, The Australian National University, Canberra.

The Gia, 2003. 'Phien toa xet xu Nam Cam va Dong bon, Doi Moi Theo Tinh Than Cai Cach Tu Phap' [Nam Cam and associates trial, a renovation in judicial reform]', Nhan Dan Newspaper website, 23 June.

Tran Dinh Thanh Lam, 2003. 'Vietnam: crackdown on corruption must go further, citizens say', Inter Press Service, 7 June. 
Tran Thi Tuyet, 2003. 'Dac diem chu yeu ve to chuc va hoat dong tu phap nuoc ta thoi ky truoc nam 1945 [Characteristics of judicial organization and operation of our country before 1945]', State and Law Reviews, No. 8, (184)/2003:13-19.

Tran Trong Kim, 2001. Viet Nam Su luoc [Vietnamese Historical Summary], Dang Nang Publishing House, Da Nang.

White, C., 1981. Agrarian Reform and National Liberation in the Vietnamese Revolution: 1920-1957, PhD Thesis, Cornell University, Ithaca, New York

Vasavakul, T., 2003. Mapping Vietnam's Legal Culture: reflections on corruption, organized crime, and state building in the post-Socialist era, Conference Paper presented at Vietnam Legal Culture Symposium, Centre for Asia Pacific Initiatives, University of Victoria, Victoria, Canada, 27-29 March. 